\title{
Marine conservation in Oceania: Past, present, and future
}

Alan M. Friedlander*

Pristine Seas, National Geographic Society, Washington, DC, USA Fisheries Ecology

Research Lab, University of Hawai'i, Honolulu, HI, USA

E-mail address: Friedlan@hawaii.edu.

This is the accepted manuscript of a paper originally published in Marine Pollution Journal. You may find the final, formatted version at 10.1016/j. marpolbul.2018.05.064.

\section{ABSTRACT}

The people of Oceania have long relied on the ocean for sustenance, commerce, and cultural identity, which promulgated a sophisticated understanding of the marine environment and its conservation. Global declines in ocean health now require innovative solutions that can benefit from customary knowledge and practices, which in the past led to sustainable marine resource use. The resurgence of local stewardship, which incorporates customary practices and governance, has shown promise in many locations throughout the Pacific, although a complete return to past practices is not fully implementable owing to the loss of traditional knowledge, centralized governmental structures, economic development, and globalization. Hybrid systems that incorporate elements of customary and contemporary management can overcome some of these limitations to implementation of successful local management, and lead to greater food security, social cohesion, and the creation of an adaptive system that can potentially mitigate the effects of climate change and other stressors.

\section{Introduction}

Owing to the failures of conventional ocean management, there is a growing interest in exploring new and innovative approaches to con- serving marine ecosystems and the benefits they provide to current and future generations. Nowhere is this more critical than in the islands of Oceania, where the ocean has provided important cultural connections and life sustaining services for millennia. The knowledge and values of indigenous peoples are increasingly being recognized as essential to the sustainable management of the coupled human-natural world (Berkes, 2012). Integrating traditional ecological knowledge and customary management practices into contemporary marine management has shown promise in many places, and these 
practices provide adaptive approaches to confront changing socio-economic and environmental conditions (Johannes, 2002a; Cinner and Aswani, 2007). Because of their long history of ocean use, much can be learned from the indigenous practices of the people of Oceania, and how these practices can contribute to innovative thinking about ecosystem-based management in the modern-day world.

In this article, I explore the knowledge and values that allowed the people of Oceania to develop sustainable use of their marine resources, followed by the demise of these systems after western colonization and the breakdown of traditional societies. The current renaissance of customary stewardship has resulted in not only more effective management, but also a cultural reawakening in many of these island nations. The integration of customary and contemporary management regimes holds great promise for reducing reliance on foreign goods and services, while also improving social cohesion. Finally, I explore how the future management of the region's marine resources may be affected by cli- mate change and other global, as well as local stressors, and how these management regimes may be able to adapt to these changes.

This review is based on my $35+$ years of experience working throughout the Pacific region, with an emphasis on artisanal fisheries and traditional and local ecological knowledge. While much has been written about various aspects of marine conservation in Oceania, this work strives to take a more holistic view of how current practices have been influenced by the culture and history of the region and how these can help inform sustainability of people and place well into the future. I conducted a comprehensive review of the literature and attempted to synthesize these findings based on my previous experiences, as well as a multitude of discussions with practitioners, researchers, and govern- mental and non-governmental actors. Although it is not possible to fully describe the wealth of knowledge and information found within this vast region, attempts were made to be as wide-ranging and unbiased as possible. The intent of this review is to provide a broad overview of past, present, and potential future stewardship and conservation approaches across Oceania, which can also help identify solutions to ocean degradation elsewhere around the world.

\section{Early colonization}

The focus of this article is on what is described as remote Oceania, which included the islands of Polynesia, Melanesia (excluding New Guinea), and Micronesia (Fig. 1, Table 1, Johannes, 1978; Bambridge, 2016). Melanesian ancestors arrived first to the region, settling in the high islands of the Western Pacific where they found abundant resources and complex topographies (Bellwood, 1980). In contrast, the resource-poor low islands of Polynesia and Micronesia provided the impetus for extensive sea travels and expansion into the outer edges of the Pacific (Sheppard et al., 2011). The first colonists to this region likely came from Southeast Asia between 4000 and 2000 BCE, 
with the earliest archaeological evidence found on the island of Saipan in the Northern Marianas Islands, dating back to 1500 BCE (Carson and Kurashina, 2012). As colonization continued to the east across ever increasing distances between islands, these people developed progressively more sophisticated navigational skills and a growing knowledge of the oceanic environment. Long before Europeans were sailing out of sight of land, Pacific Island navigators were voyaging thousands of kilometers across the entire Pacific (Finney, 1977). The knowledge acquired as these islanders crossed this vast region led to the creation of social systems that fostered sustainable use of the marine environment.

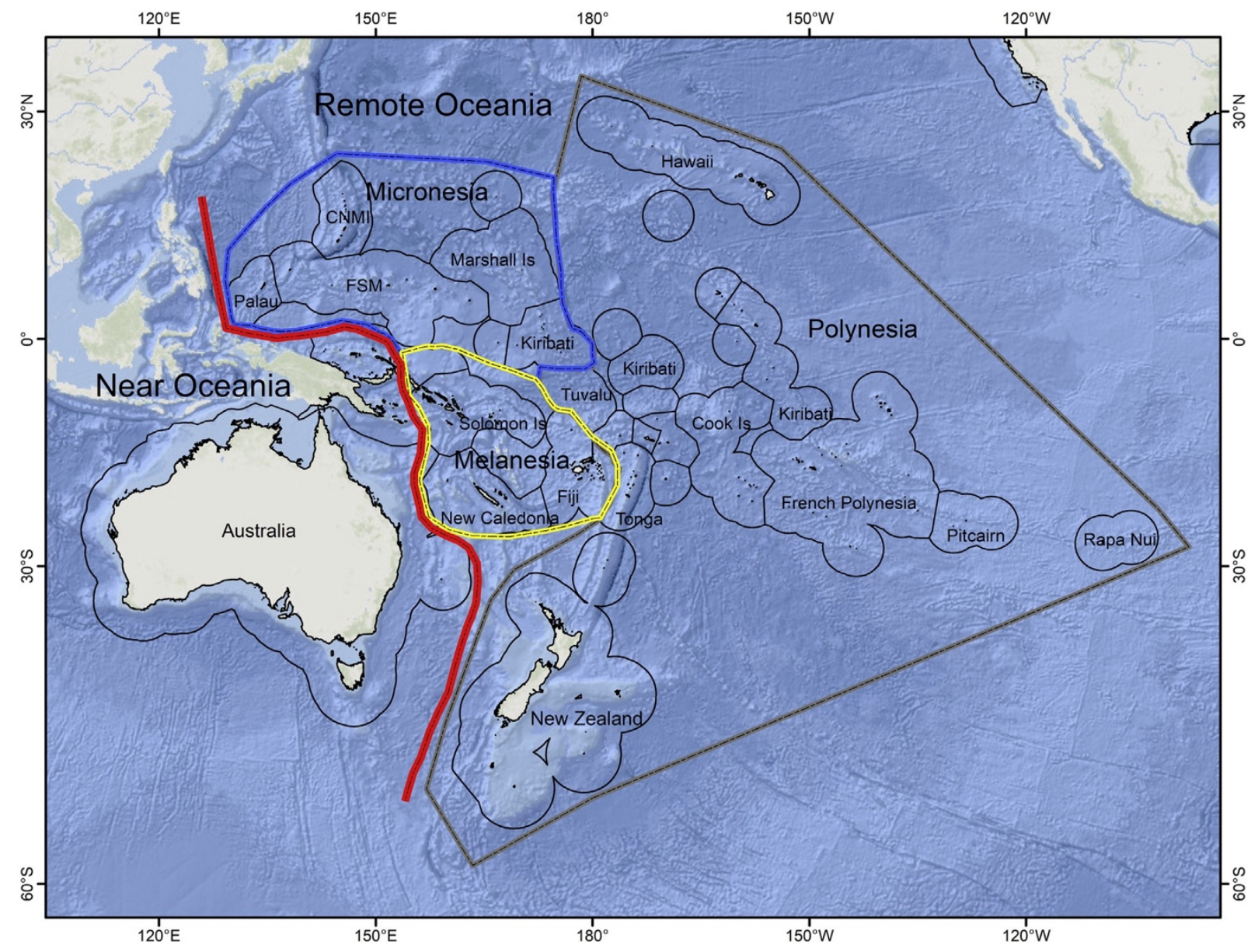

Fig. 1. Near and remote Oceania.

(From Johannes (1978) and Bambridge (2016).)

While there is evidence that the regions that make up Oceania had different processes of cultural diversification owing in part to environmental settings and the differential size of the islands (Sand, 2002), many communities throughout the tropical Pacific share a similar knowledge of basic resource conservation principles that are the result 
of centuries of continuing experimentation and innovation (Wilhelm et al., 2014). Localized adaptive management was based on customary knowledge and practices and was responsive to changes in local environmental and social conditions (Ruddle, 1996; Johannes, 1998a). Long before western societies recognized the limits of ocean resources, the people of Oceania developed methods to safeguard against the collapse of these invaluable resources (Johannes, 1978). Their long history of conservation was motivated by scarcity, limited resources, and climate variability. Some species were referred to as 'famine foods', suggesting that food needs were not always met (Titcomb, 1972). Some Pacific Island cultures learned that their re-sources were limited and introduced appropriate conservation measures, while others exceeded those limits, which ultimately led them to overshoot their carrying capacity (Johannes, 2002a; Tainter, 2006).

Not all these practices were developed for conservation purposes; many had cultural roots and were designed to maintain political structure and order (Ruddle, 1996;

Colding and Folke, 2001). In contrast to the densely populated islands of Polynesia and Micronesia, human population densities in parts of Melanesia prior to European colonial intrusions were likely too low to have generated sufficient fishing pressure to drive the evolution of a conservation ethic (Foale et al., 2011; 2016). Therefore, customary marine tenure and fishing taboos in this region were primarily designed to manage relationships between social groups, rather than to sustain food security (Foale et al., 2016). Although tenure and taboo systems were not inherently de- signed to ensure sustainable management outcomes in these areas, stable resource availability for local use was sometimes a by-product (Jupiter, 2017).

In parts of Oceania, especially lightly populated coastal areas of Melanesia, marine resources existed in quantities sufficient for the needs of the local populations to be met (Johannes, 1989). In some of these areas, there is little evidence of a marine conservation ethic, be- cause people never experienced overexploitation of these resources (Johannes and MacFarlane, 1991) or relied more heavily on terrestrial resources for sustenance (Chapman, 1985). Traditional political structure also played a role in conservation in Oceania. In Polynesia and Micronesia, political authority was through heredity and these lineages were considered of divine origin, while in Melanesia, leadership was often acquired through achievements such as wealth accumulation, oratory skill, courage in warfare, or benevolence toward their followers (Chapman, 1987). Because of greater social stratification, higher occupational specialization, and larger political units, Polynesian and Micronesian societies often had a greater emphasis on conservation knowledge and practices compared with Melanesia.

The people of Oceania relied on the sea for much of their protein, as well as other essential nutrients and minerals that were lacking in the poor-quality soils of many atolls and small islands (Johannes, 1978). In addition, other important resources such as building materials, fishing gear, jewelry, medicines, and household tools were 
obtained from the sea. Marine resource management was often in the hands of the local resource users who were knowledgeable of the natural rhythms and processes that controlled resource abundance (Johannes, 1978; Poepoe et al., 2007). Fishermen were often held in high regard within the community and master fishermen held extensive knowledge that was passed down from generation to generation (Titcomb, 1972; Johannes, 1982).

Many fishing restrictions were associated with spiritual and cultural beliefs. Certain species that were considered sacred were often rare or susceptible to overfishing, and as a result were prohibited from consumption by certain groups (e.g., women, commoners, clans, age groups) (Abbott, 1984). For example, turtles were typically reserved for chiefs in many locations throughout Oceania (Allen, 2007). In Hawai'i, only ruling chiefs could consume Pacific threadfin (Polydactylus sexfilis), which is a protandric hermaphrodite (changing sex from male to female), and therefore particularly vulnerable to overharvest (Friedlander and Ziemann, 2003).

Species of importance often have multiple names, depending on various life history characteristics (e.g., size, sex, color). In Rapa Nui, the rudderfish Kyphosus sandwicensis, locally known as nanue, in one of the most important nearshore fisheries species and has seven secondary names based on size and five secondary names based on color pattern (Randall and Cea, 2011). Names were also associated with various life history phases, which often connoted an understanding of the ecology of the species. In Palau, the juvenile stage of the sweetlip Plectorhinchus obscurus (bikl) lives at mangrove edges near river mouths, where it is called melimralm, which means to drink fresh water (Helfman and Randall, 1972). These distinctions often had important conservation and management implications. Hawaiians recognized four life history phases for the hermaphroditic Pacific threadfin (juveniles - moi li'i, males - mana moi, hermaphrodites - pala moi, and female - moi), and conservation principles included restrictions on harvest of pala moi or moi, depending on inter-annual fluctuations in population structure (Poepoe et al., 2007).

Societies were strongly stratified through chieftainships and com-munity leadership that were based on matrilineal or patrilineal systems, which were inherited and/or merit-based and often associated with ritual and spiritual protocols (Lal and Fortune, 2000). The first fish of a catch was often offered to the gods, and the next fish to the chief, before consumption by an individual (Bambridge, 2016). In Hawai'i, gathering of shellfish and seaweed was primarily conducted by women, and their harvest was then surrendered to the representative of the high chief who would divide it among the community (Titcomb, 1978). Despite this hierarchy, the egalitarian nature of many Pacific Island cultures meant that food was shared among most sectors of society (Allen, 2007). Sharing also helped maintain kinship and other social linkages, which reinforced reciprocal sharing during seasonal shortages or other times of need (Campbell, 2015). 
Many of the marine management rules and regulations we have today (e.g., closed areas, closed seasons, size restrictions, restricted entry) were employed thousands of years ago by Pacific Islanders (Johannes, 1998a). The traditional systems in many of these islands emphasized social and cultural controls on marine resource use, with a code of conduct that was strictly enforced (Johannes, 1982; Ruddle, 1988). Draconian penalties were often administered for violating these restrictions owing to the importance of maintaining a secure food supply and social order.

Pacific Islanders developed an encyclopedic knowledge of their re- sources, especially as they related to seasonal movements, feeding behavior, and spawning seasons and locations (Johannes, 1981, 1982). Approaches to harvest management were often based on identifying the specific times and places that fishing could occur so as not to disrupt basic processes and habitats of important food resources (Johannes and Yeeting, 2001; Poepoe et al., 2007). Many natural processes affect the distribution of these marine resources, but some of the most important are related to seasons and moon phases. This knowledge helped to in-form lunar calendars, which were mental models based on a holistic understanding of marine and terrestrial environments and emphasized certain repetitive ecological processes (e.g., spawning, aggregations, feeding habits) that function at different time scales (e.g., seasonal, monthly, and daily), which were adapted to fishermen's own observations for specific locations (Friedlander et al., 2002; Poepoe et al., 2007).

The most important marine conservation measure in Oceania was local marine tenure, where the right to fish in a location was controlled by a clan, chief, or family (Johannes, 1978; Ruddle et al., 1992). Spatial closures within these tenure systems were employed throughout Oceania for various purposes, and these closures were often imposed to ensure large catches for special events, or as a cache for when resources in the commonly accessed fishing grounds ran low (Johannes, 1978; Cinner et al., 2006). Temporal closures were widely used to reduce intensive harvest of spawning fishes or other predictable aggregations (e.g., migration routes, Johannes, 1978, 1981). The collective practices described above were developed through much trial and error and fostered sustainability under highly variable and scare resource conditions.

\section{Post-western contact}

\section{European colonization}

The age of European exploration of the Pacific began with the voyage of Magellan in 1519-21, which led to the rise of global trade and the creation of European colonial empires throughout the region. Except for the interiors of the largest Melanesian islands and some small and remote islands, missionaries soon penetrated much of the 
region, and by the late nineteenth century entrepreneurial traders from Europe and the US were present throughout Oceania. Soon after western con- tact, depopulation of the native peoples occurred in many areas due to disease and servitude.

The whaling industry, primarily centered in Hawai'i but also pre- valent in Guam, Fiji, Pohnpei, Tahiti, and the Gilbert Islands, led to great economic and social transformation (Lal and Fortune, 2000). Pacific Islanders began to supply labor for provisioning European ships, and as crew, while also becoming involved in the extraction and processing of marine products (Lal and Fortune, 2000). Europeans and Americans involved in the China trade established export fisheries for bêche-de-mer (dried sea cucumber) in the early 1800s throughout Oceania (Preston, 1993). Bêchede-mer traders introduced firearms and trade goods such as iron tools and fishhooks, which led to increased efficiencies, but also increased conflict, leading to major demographic and political changes in the region (Ward, 1972).

The establishment of cash economies and the presence of foreigners led to the development of commercial fisheries around many islands to feed and resupply merchant ships and the ever-growing non-native populations. Commercialization of fishing created distance markets and led to a dismantling of the conservation ethic in many locations. In Hawai' $i$, the early 1900s saw the centralization of economic activities and fisheries with large increases in commercial fish landings. The Hawaiian Tuna Packing Company began operations in 1917 and by the 1930s employed 500 men and produced nearly ten million cans of tuna per year, making it the third largest export commodity in Hawai'i at that time, behind sugar and pineapple (Schug, 2001).

Traditional local authority mostly disintegrated due to colonization, commercialization, and economic development (Johannes, 1978; Ruddle and Hickey, 2008). In Kiribati many traditional marine management practices were abandoned during the colonial era, and customary marine management is now uncommon in the country (Vierros et al., 2010). Colonial governments were generally ignorant of traditional management structures and introduced various types of in- effective centralized natural resource management policies that often greatly weakened local authority (Johannes, 1998b).

\section{Post-colonial rule}

World War II brought about profound changes in the Pacific - once remote and isolated villages were rapidly exposed to an entirely new world view. Following World War II, many countries gained in- dependence, while others developed various forms of association with their former colonial powers (Table 1). The shift to market-based economies led to increased commercialization of fisheries, particularly industrial tuna fishing (Barclay, 2014). While the economic value and total tonnage of the industrial tuna catch dwarfs all other fisheries in Oceania, coastal fisheries are far more important for livelihoods and food security, as well as cultural identify (Gillett, 2009). 
These near- shore fisheries also became increasing commercialized with assistance from international and national interests.

Table 1

Country, territory, states within remote Oceania. EEZ - Exclusive Economic Zone. Land $=\mathrm{km}^{2}$, Pop density $=$ people $\mathrm{km}^{-2}$.

\begin{tabular}{|c|c|c|c|c|c|}
\hline Country, territory, state & Governance type & Pop. & EEZ & Land & Pop density \\
\hline \multicolumn{6}{|l|}{ Polynesia } \\
\hline Am. Samoa (USA) & Territory of USA & 54,194 & 405,844 & 197 & 275.1 \\
\hline Cook Islands & Self-governing in free assoc. w/ NZ (1965) & 19,379 & $1,969,507$ & 180 & 107.7 \\
\hline French Poly. (Fra.) & Overseas collectivity of France & 280,208 & $4,766,884$ & 3521 & 79.6 \\
\hline Hawai'i (USA) & State of USA (1959) & $1,428,557$ & $2,480,124$ & 16,636 & 85.9 \\
\hline Kingdom of Tonga & Constitutional monarchy & 103,036 & 666,079 & 696 & 148.0 \\
\hline Niue (NZ) & Self-governing state in free assoc. w/ NZ (1974) & 1624 & 318,144 & 258 & 6.3 \\
\hline Pitcairn Is. (UK) & British overseas territory w/ local government & 55 & 842,345 & 5 & 11.0 \\
\hline Rapa Nui (Chile) & Special territory of Chile & 6600 & 729,763 & 164 & 40.2 \\
\hline Samoa & Independent (1962) & 192,342 & 130,474 & 2934 & 65.6 \\
\hline Tokelau (NZ) & Dependent territory of NZ & 1499 & 320,617 & 12 & 124.9 \\
\hline Tuvalu & Independent from UK (1978) & 10,640 & 753,126 & 26 & 409.2 \\
\hline Wallis \& Futuna (France) & French overseas collectivity & 11,899 & 262,751 & 124 & 96.0 \\
\hline \multicolumn{6}{|l|}{ Micronesia } \\
\hline CNMI (USA) & Commonwealth of USA & 53,467 & 763,555 & 475 & 112.6 \\
\hline FSM & Self-governing in free association w/ USA since 1979 & 104,937 & $3,010,628$ & 702 & 149.5 \\
\hline Guam (USA) & Unincorporated territory of USA & 162,742 & 208,211 & 549 & 296.4 \\
\hline Republic of Nauru & Independent since 1968 from UN trust of NZ, Australia, and UK & 10,084 & 309,261 & 21 & 480.2 \\
\hline Republic of Kiribati & Independent from UK since 1979 & 110,136 & $3,439,873$ & 726 & 151.7 \\
\hline Republic of Palau & Presidential republic in free association with US since 1982 & 21,503 & 614,805 & 500 & 43.0 \\
\hline Republic of the Marshall Islands & Independent (1979), Compact of Free Association with USA (1986) & 53,066 & $2,001,386$ & 720 & 73.7 \\
\hline \multicolumn{6}{|l|}{ Melanesia } \\
\hline New Caledonia (France) & Special collectivity of France & 286,767 & $1,175,906$ & 19,103 & 15.0 \\
\hline Republic of Fiji & Independent from UK (1970) & 879,760 & $1,283,244$ & 18,376 & 47.9 \\
\hline Solomon Islands & Independent from UK (1978) & 599,419 & $1,605,256$ & 29,785 & 20.1 \\
\hline Vanuatu & Independent from UK \& France (1980) & 270,402 & 623,417 & 12,189 & 22.2 \\
\hline
\end{tabular}

The post-war period witnessed the growth of regionalism. Regional conservation action in Oceania illustrates how mechanisms for inter- national cooperation, standard setting and implementing institutions such as convention secretariats are mutually supportive, with interested governments, non-governmental organizations and international organizations working together through a combination of formal agreements, action plans, intergovernmental meetings and scientific symposia to build interest in and capacity for nature conservation in the region (Dahl, 2017). The South Pacific Commission (SPC, now known as the Pacific Community) was formed in 1947 as the principal scientific and technical organization in the region. In 1971, the newly independent states formed the South Pacific Forum, renamed the Pacific Islands Forum (PIF), to address political and social issues. The Forum Fisheries Agency, created in 1979, negotiates licensing agreements with foreign fishing companies on behalf of the PIF members. In 1982, the South Pacific Regional Environment Program, was established by SPC, PIF, and the United Nations, to promote sustainable development throughout the region. The Council of Regional Organizations in the Pacific under the PIF ensures cooperation among the regional organizations, both governmental and non-governmental. 
Beginning in the 1970 , secondary education programs began to develop more relevant curricula for Pacific Island schools that included an indigenous perspective (Thaman, 1993). The University of the South Pacific has provided higher education to students from throughout the region since 1967 and now has 14 campuses across 12 countries. Other universities that serve the region include the University of Guam, the University of Hawai'i system, the National University of Samoa, the University of French Polynesia, and the University of New Caledonia.

\section{Present}

\section{Impacts of globalization}

Modernization and a cash economy have driven many coastal communities to overexploit their resources, often at the expense of the very resources on which they rely. Declines in marine resources have resulted from myriad factors including: intensive fishing pressure, land based pollution, destruction of habitat, and invasive species. The distal drivers of these declines stem from growing human populations, cash economies and globalization, access to technological innovations (e.g., motorized boats and freezers for storing catch), introduction of overly efficient fishing techniques (e.g., inexpensive monofilament gill nets, scuba, GPS), and loss of traditional conservation practices (Johannes, 1978; Cinner and Kittinger, 2015). In the Solomon Islands, the use of more efficient gear was positively related to both human population density and market proximity, which collectively contributed to declines in marine resources (Brewer et al., 2013).

Most Pacific Island countries and territories do not have coastal fisheries policies, and the low levels of government support and the large spatial scale of these coastal resources present significant management challenges (Gillett and Cartwright, 2010; Govan, 2015). Poor government effectiveness is, in part, a result of under-resourced agencies, particularly in rural areas where the fisheries mostly occur (Govan et al., 2013). The lack of effective coastal management has led to a call for the development of innovative solutions to address these problems.

\section{Renaissance of customary management}

Recognition that westernization produced a concomitant decline in marine resources and cultural identity has led to a revival of customary management practices throughout Oceania. This resurgence is being driven by increasing scarcity of resources, re-establishment of local authority and tenure, improved education, and more effective assistance and advice from governmental and non-governmental organizations (Johannes, 2002 b). In many locations customary management systems have achieved positive social outcomes by improving local social order and identity, 
which promotes historical continuity and links ancestry and place (McClenachan and Kittinger, 2013; Cinner and Huchery, 2014). This localized management also reduces the cost of enforcement, as well as social and political conflicts (Hviding, 1998).

The success of community tenure of marine resources is often related to the proximity of the community to their area of responsibility, and to the level of cultural and social cohesion extant within the community (Aswani, 2005; Cinner et al., 2012). Local authority is most relevant in remote areas where centralized government is not costeffective nor effectual. Even where state institutions exist at the local level, they coexist with customary institutions, resulting in 'legal pluralism', or the existence of multiple legal systems within one geo- graphic area (Corrin Care and Zorn, 2001; Bambridge, 2016).

Throughout much of Oceania, compliance with local resource management rules relies to a large extent on respect for traditional authority and decision-making processes (Aswani, 2005; Hoffmann, 2002). Current barriers to compliance include conflict between customary management rules and national legal frameworks, as well as incentives to overfish from growing global markets (Clarke and Jupiter, 2010). National legislation in many Pacific island countries recognizes and protects indigenous land tenure; however, recognition of customary marine tenure has been more uneven, reflecting a historical conflict between Pacific marine tenure systems and the 'open access' traditions of colonizing European states (Govan et al., 2009; Clarke and Jupiter, 2010). In Fiji, enforcement of community management rules is constrained by the national legal system, whereas local communities have no formal authority to enforce management rules, and certain community-imposed sanctions may breach national criminal laws (Veitayaki, 2000).

\section{Locally managed marine areas}

Communities throughout Oceania are currently engaged in bottom- up management of their coastal and marine resources with technical support and resources from groups such as the Locally-Managed Marine Area network (LLMA, Jupiter et al., 2014). LMMAs are often supported and guided by co-management partners (e.g., NGOs, government agencies, or research institutes) who promote a diverse range of objectives, including biodiversity conservation, fisheries management, livelihood diversification, and climate change adaptation (Weeks and Jupiter, 2013). However, for most communities the main driver for local management is the desire to maintain or improve livelihoods and is often related to perceived threats to food security, commerce, or culture (Govan et al., 2009). More than 900 communities, comprising $8 \%$ of coastal communities in the Pacific region, are documented as having implemented Community-Based Fisheries Management (CBFM, Govan, 2015). However, more than half of these CBFMs are in Fiji and Samoa, leaving $>90 \%$ of the coastal villages in the region without support to implement local management (Table 2). There are likely hundreds to thousands of communities throughout the Pacific implementing their own coastal and marine 
actions that are not officially documented and therefore lack support from government institutions (Jupiter et al., 2014; Govan, 2015). Despite their proliferation and popularity, there are relatively few empirical examples describing how these areas were established or how they are performing from either an ecological or socioeconomic perspective (Jupiter et al., 2014; Wamukota et al., 2012).

In Hawai'i, communities can enter co-management with the State to protect Native Hawaiian subsistence, cultural, and religious fishing practices (Ayers and Kittinger, 2014). Despite interest from $>19$ communities only two communities in over 20 years have been successfully designated, and none have approved management plans (Levine and Richmond, 2014). This co-management approach has been hindered by a lack of capacity in communities and institutional rigidity at resource management agencies, as well as an ambiguous, complicated administrative rulemaking processes. Despite the numerous obstacles to formal governmental authorization, numerous communities in Hawai' $i$ are strengthening local influence and accountability for their marine resources, oftentimes independent of government support (Friedlander et al., 2013, 2014).

\section{Hybrid management}

Integrating traditional ecological knowledge and customary practices into contemporary marine management has shown promise in many locations (Cinner, 2005; Kittinger et al., 2014). Hybridization of customary beliefs and institutions with modern management concepts such as marine protected areas (MPAs) and ecosystembased management (EBM) can help address broader concerns such as coastal degradation, climate change, weak governance, corruption, limited re-sources, and increasing poverty (Aswani and Ruddle, 2013). This integration is particularly relevant in coastal communities that have or have had traditional rights-based fishery management systems and/or are more socio-culturally homogeneous (Aswani, 2005).

Customary and contemporary 'western-style' systems of governance often have different objectives, values, and time horizons that can lead to conflict. While there are distinct differences between customary and contemporary regimes, there are commonalities that can lead to effective management. The Pacific Islanders' holistic world view of the inseparability of people and nature corresponds largely with the principles of EBM, recognizing the strong interdependencies of ecological, social, economic, and institutional perspectives. Local tenure allows inclusive members to institute spatial and temporal restrictions that also lie at the core of EBM. Customary tenure systems have hybridized with modern rights-based fisheries management measures such as individual transferable quotas (ITQs), as in the Trochus fisheries in the Cook Islands and Vanuatu (Aswani, 2005; Hickey and Johannes, 2002). The perceived success of hybrid MPAs in Samoa and Vanuatu has in- spired neighboring communities to adopt similar strategies (Johannes, 2002b). 
Closing certain areas to harvest for periods of time has been practiced for centuries by Pacific Islanders to help sustain healthy populations of marine resources (Johannes, 1978, 1982; Cinner et al., 2006). Incorporating elements of these established practices into a con- temporary framework has shown biological and social success, and can increase the legitimacy of decisions regarding MPAs, as well as aid in compliance (Aswani et al., 2012). Incorporating fishermen's local knowledge into designing marine protected areas in the Solomon Is- lands produced conservation areas that represented natural and social seascapes recognized by indigenous communities (Aswani and Lauer, 2006). Protection of spawning sites is a central tenant of MPA design, and identification and conservation of these aggregations has been greatly aided by traditional and contemporary fishers' knowledge (Johannes, 1998a, 1998b; De Mitcheson et al., 2008).

In Palau, conservation has evolved from the traditional "bul" to more contemporary MPAs with effective enforcement, by most standards, owing to strong community support (Gruby and Basurto, 2013; Friedlander et al., 2017). In Fiji, where enforcement capacity rests largely with communities, most MPAs are located near communities to improve surveillance (Jupiter and Egli, 2011). In many cases, opportunistically placing MPAs where there is community support may be more beneficial than implementing, or failing to implement, a more optimal design in the future (Ban et al., 2011).

Permanent "western-style" area closures have been implemented throughout the region, particularly in more developed localities where customary practices are less prevalent. In areas where customary tenure is strong, permanent "no-take" reserves are likely to be disregarded, owing to concerns for human welfare or different objectives as seen by the community (Aswani et al., 2012). However, in some more urban areas and areas where customary or local management is weak due to increased market influence, population size, immigration and development, imposition of larger no-take areas may be a more effective strategy.

The establishment of permanent or indefinite closures appears to be a departure from customary practices, and this shift may be due, in part, to both declining resources and changing social structure (Bartlett et al., 2009). Periodic closures based on customary norms are likely most effective where local socio-cultural institutions are strong, and communities have the capacity to enforce regulations (Johannes, 2002b; MuehligHofmann, 2007). Some have argued that permanent no-take closures are largely incompatible with customary tenure be- cause the scale of population replenishment for most marine species is considerably larger than that of most community-based management area boundaries (Foale and Manele, 2004). However, localized recruitment of many species has been shown to be important for many nearshore species, and networks of no-take areas can enhance regional population replenishment (Grorud-Colvert et al., 2014). One example is Palau where the government was instrumental in establishing 
the Micronesia Challenge - a conservation initiative to protect $>30 \%$ of the marine ecosystems of the region by 2020 through the establishment of a Protected Areas Networks, which been shown to be successful from at least an ecological perspective (Baker et al., 2011; Friedlander et al., 2017). Elsewhere in Micronesia, MPA effectiveness varies widely and depends on the proximity to human populations, the level of reef degradation, and wave exposure, which can be a proxy for accessibility (Houk et al., 2015). In Fiji, efforts are underway to scale up its LMMA network by encouraging communities to work together with adjacent communities (Mills et al., 2011).

The World Database on Protected Areas (WDPA, UNEP-WCMC and IUCN, 2018) maintains information on marine and terrestrial protected areas. Most countries in Oceania do not maintain up to date lists of MPAs and therefore reported areas should be treated with caution. As reported in the WDPA, most of the marine protected areas in Oceania have some form of local co-management (Table 2). Solely government managed MPAs are less common and are often associated with remote locations, important conservation areas (e.g., spawning sites), or to benefit tourism. Despite government control, local influence is still important in the management of many of these MPAs. 
Table 2

Marine managed areas in remote Oceania. Data from World Database on

Protected Areas (UNEP-WCMC and IUCN, 2018; Govan, 2015; O'Leary et al., 2018). Local management areas include: indigenous owners, communities, in- dividual landowners, joint and collaborative.

\begin{tabular}{|c|c|c|c|}
\hline $\begin{array}{l}\text { Region/country- } \\
\text { territory }\end{array}$ & $\begin{array}{l}\text { No. CBFMa } \\
\text { (\% of total) }\end{array}$ & $\begin{array}{l}\text { Government } \\
\left(\mathrm{km}^{2}\right)\end{array}$ & $\begin{array}{l}\text { Local management } \\
\left(\mathrm{km}^{2}\right)\end{array}$ \\
\hline \multicolumn{4}{|l|}{ Ivieıanesıa } \\
\hline Fiji & $448(53 \%)$ & - & 12,696 \\
\hline New Caledonia & $1(\mathrm{ND})$ & 3747 & 8884 \\
\hline Solomon Is. & $184(5 \%)$ & 155 & 1414 \\
\hline Vanuatu & $13(1 \%)$ & - & 123 \\
\hline \multicolumn{4}{|l|}{ Micronesia } \\
\hline FSM & $10(13 \%)$ & $472^{b}$ & 3 \\
\hline Guam & 0 & 15 & 4 \\
\hline Kiribati & $5(3 \%)$ & $539^{c}$ & - \\
\hline Marshall Is. & $13(13 \%)$ & - & 7470 \\
\hline N. Mariana Is. & 0 & 14 & 8 \\
\hline Nauru & 0 & - & - \\
\hline Palau & $5(31 \%)$ & - & 1104 \\
\hline \multicolumn{4}{|l|}{ Polynesia } \\
\hline Am. Samoa & $13(18 \%)$ & - & 23 \\
\hline Cook Is. & $6(16 \%)$ & - & 2 \\
\hline Niue & $1(7 \%)$ & - & 54 \\
\hline Pitcairn Is. & 0 & - & - \\
\hline French Polynesia & $27(56 \%)$ & 207 & - \\
\hline Rapa Nui & 0 & - & - \\
\hline Tokelau & $3(100 \%)$ & 10 & - \\
\hline Samoa & $102(31 \%)$ & 8 & 107 \\
\hline Tonga & $10(6 \%)$ & $37^{\mathrm{d}}$ & 158 \\
\hline Tuvalu & $9(100 \%)$ & 40 & 24 \\
\hline Wallis and Futuna & 0 & - & - \\
\hline
\end{tabular}

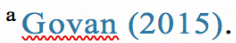

b $99 \%$ in Oroluk Sanctuary - subsistence fishing by residents only.

${ }^{c} 60 \%$ on Kiritimati Atoll.

${ }^{\mathrm{d}}$ Excluding Ha'apai Archipelago, which is a multi-use conservation area $\left(9879 \mathrm{~km}^{2}\right)$.

Some conservation measures have violated the rights of indigenous peoples, resulting in poverty and societal problems (Colchester, 2004). The term "ocean grabbing" has been used to describe actions, policies or initiatives that deprive small-scale fishers of resources, dispossess vulnerable populations of coastal lands, and/or undermine historical access to areas of the sea (Bennett et al., 2015). These concerns high- light the need for proponents and implementers of ocean-related initiatives involving reallocation of space or resources to incorporate input from and be mindful of potential consequences to local communities. 


\section{Large-scale MPAs}

Increasing attention is being paid to the natural and cultural heritage value of remote ocean spaces and this recognition has led to the designation of Large-Scale MPAs (LSMPAs, $\geq 100,000 \mathrm{~km}^{2}$ ), particularly in Oceania (Toonen et al., 2013; Wilhelm et al., 2014). These LSMPAs offer benefits that are not obtainable at smaller scales, primarily the ability to protect whole ecosystems and interdependent habitats so that biologically connected ecosystems can be included within the same management area (Toonen et al., 2013). Large no-take LSMPAs have been established in several areas (e.g., Hawai'i and US Pacific, Palau, Pitcairn, Kiribati), while a few jurisdictions have declared or promised to create their entire EEZs as multi-use LSMPAs (O'Leary et al., 2018; Fig. 2, Table 3).

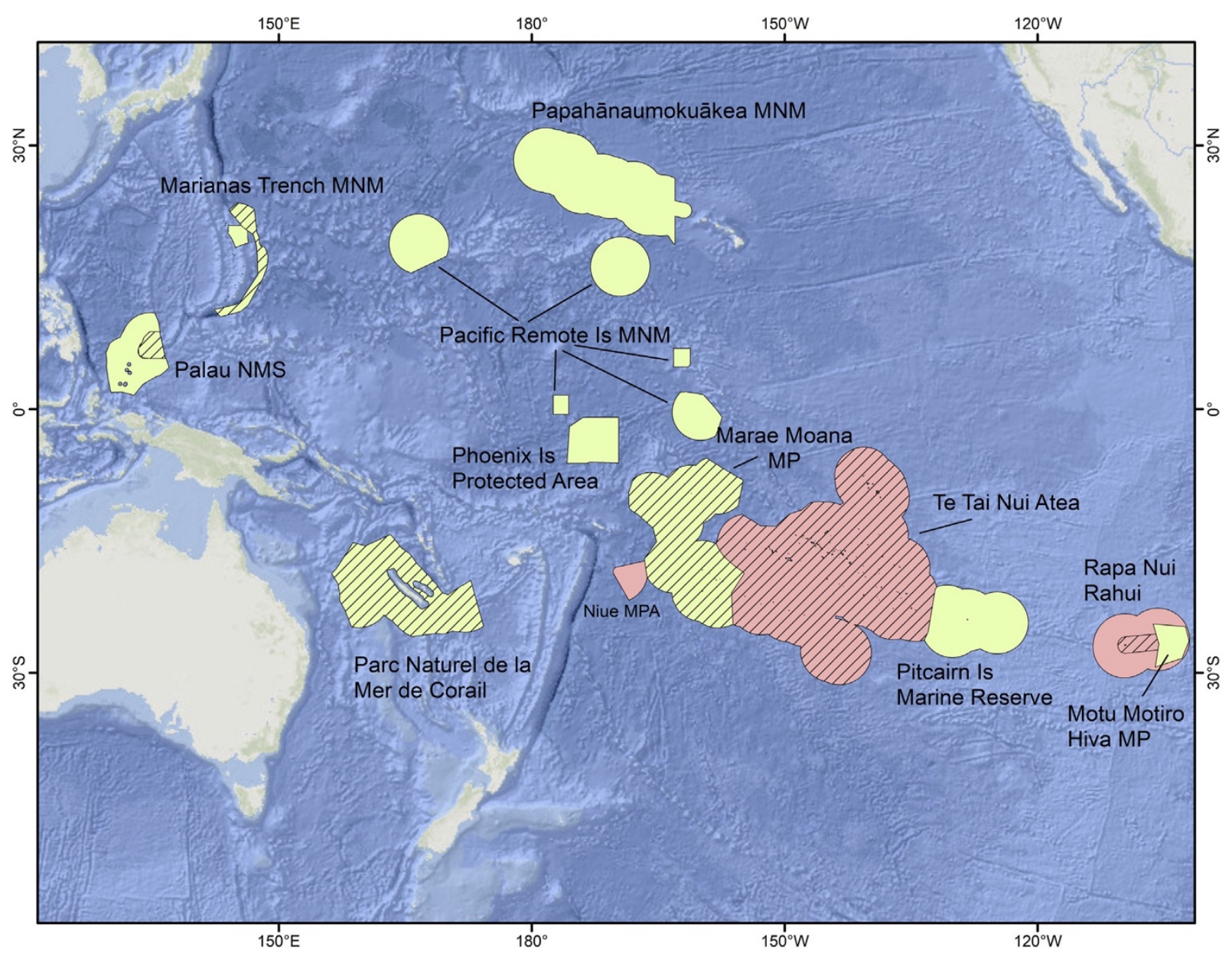

Fig. 2. Distribution of designated and promised LSMPAs in Oceania as of June 2017. LSMPAs that are designated are in olive and those promised are in pink. Multiple-use MPAs are designated by hatched lines. Strongly or fully protected are shown without hatches. MNM - Marine National Monument, NMS - National Marine Sanctuary, MP 
- Marine Park. Should Easter Island Marine Park be designated, Motu Motiro Hiva MP would be encompassed by this designation. (adapted from O'Leary et al., 2018). (For interpretation of the references to color in this figure legend, the reader is referred to the web version of this article.)

Table 3

Large-scale Marine Protected Areas (LSMPAs) in Oceania. Year is the year proposed. Data from O'Leary et al. (2018).

\begin{tabular}{|c|c|c|c|c|c|}
\hline LSMPA name & Country & Year & Designated & Area $\left(\mathrm{km}^{2}\right)$ & Management type \\
\hline Parc Naturel de la Mer de Corail, New Caledonia & France & 2014 & Yes & $1,291,643$ & Multi-use \\
\hline Phoenix Is. Protected Area & Kiribati & 2008 & Yes & 408,250 & Strong protection \\
\hline Marianas Trench Marine National Monument & USA & 2009 & Yes & $246,608^{\mathrm{a}}$ & Multi-use \\
\hline Palau National Marine Sanctuary & Palau & 2015 & Yes & $503,521^{b}$ & Strong protection \\
\hline Marae Moana Marine Park & Cook Is & 2017 & No & $1,900,000$ & Multi-use \\
\hline Niue Marine Park & Niue & 2017 & No & 127,000 & Strong protection \\
\hline Pitcairn Is. Marine Reserve & UK & 2016 & Yes & 834,334 & Strong protection \\
\hline Te Tai Nui Atea, French Polynesia & France & 2017 & No & $5,000,000$ & Multi-use \\
\hline Rapa Nui Rahui MPA & Chile & 2015 & No & $720,016^{c}$ & Strong protection \\
\hline Motu Motiro Hiva Marine Park & Chile & 2010 & Yes & $150,340^{c}$ & Strong protection \\
\hline Papahanaumokuakea Marine National Monument & USA & 2006 & Yes & $1,508,859^{d}$ & Strong protection \\
\hline Pacific Remote Islands Marine National Monument & USA & 2009 & Yes & $1,269,094^{\mathrm{e}}$ & Strong protection \\
\hline
\end{tabular}

${ }^{a}$ Commercial fishing is permitted in waters of the Trench and Volcanic Units but not in the Islands Unit of the Monument $(\sim 17 \%)$.

${ }^{b}$ Palau National Marine Sanctuary fully protects $80 \%$ of the EEZ with the remainder reserved for domestic fishing only.

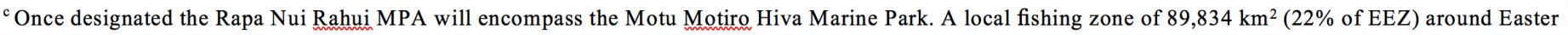
Island will permit the Rapa Nui to continue using the marine resources.

d Expanded from 362,061 in 2016.

e Expanded from 214,969 in 2014.

Many of the existing LSMPAs are remote areas in the Pacific that share common natural history, threats, culture, as well as scientific and management needs. The distinctive challenges faced by LSMPAs, especially the governance and protection of vast tracks of open ocean, led to the formation of a unique conservation organization in 2010, 'Big Ocean: A Network of the World's Large-Scale Marine Managed Areas' (http://bigoceanmanagers.org), which is a peer-to-peer learning and sharing network of LSMPA managers (Wilhelm et al., 2014). Several LSMPAs in the Pacific have collaborated in bilateral agreements, and learning exchanges, as well as research, monitoring, and enforcement activities (Friedlander et al., 2016). Papahānaumokuākea Marine National Monument (PMNM) is one of the world's largest MPAs (> 1.5 million $\mathrm{km}^{2}$ ) and its UNESCO World Heritage inscription identified its outstanding universal value for both natural and cultural heritage, and as the world's first cultural seascape for its continuing connections to indigenous people (Kikiloi et al., 2017). Management of PMNM emphasizes integration of science, policy, cultural knowledge, traditions, and practices to create successful management strategies appropriate for both natural and cultural resources. 
The creation of LSMPAs is not without controversy. The rapid growth of LSMPAs runs the risk of being biased toward places that are remote or unpromising for extractive activities and hence residual to commercial uses (Devillers et al., 2015). In addition, the implementation and the management of LSMPAs have not been well explored in practice or theory (Leenhardt et al., 2013). Some of the criticisms of LSMPAs are valid and need addressing, however, none pertain exclusively to LSMPAs and many involve challenges ubiquitous to all management (O'Leary et al., 2018).

\section{Future}

It is estimated that coastal fisheries of most countries and territories in the region will not meet their food security needs by 2030 due to population growth, overfishing, reduced productivity because of cli-mate change, and inadequate national distribution networks (Hanich et al., 2018). The stagnation of coastal fishery production and the lack of management investment means food and employment must be spread among a growing number of people. The utility of nearshore fisheries laws in the face of climate change requires resilient coastal fisheries policies (Gourlie et al., 2018). New legislation with the ap-propriate balance between state-driven management efforts and bottom-up community stewardship must allow for management flexibility to ensure that scientific understanding of climate effects supports management decisions, and minimizes adverse effects of climate change on the lives, livelihoods, and rights of communities. Improving coastal fisheries management in the short term should be better ad-dressed through improved management frameworks, use of human re- sources, and allocation of increased and decentralized budgets. An example of this is the Pacific Oceanscape Initiative, which has been endorsed by 23 Pacific Island nations, regional intergovernmental agencies, and the conservation community to advocate for conservation and sustainable development of $\sim 40$ million $\mathrm{km}^{2}$ of Pacific Ocean (Govan, 2017).

\section{Climate change}

Global climate change is imperiling ecosystems worldwide, but especially in Pacific Islands, which is one of the most vulnerable regions to climate change impacts (Bell et al., 2013; Cheung et al., 2016). Climate change is already affecting the region through increasing temperatures, sea-level rise, saltwater intrusion of freshwater resources, coastal erosion, an increase in extreme weather events, altered rainfall patterns, coral bleaching, and ocean acidification (Hanich et al., 2018). Potential pelagic fish catch is projected to decrease by $>50 \%$ across many areas, with the largest impacts in the western Pacific (Cheung et al., 2016). However, these impacts will be in even more pronounced in coastal regions, with significant declines expected in the abundance of nearshore fisheries species, including export products such as Trochus and bêche de mer, due to degradation of coral reefs and other essential habitats, such as mangroves and seagrass beds (Bromhead et al., 2015). 
Pacific Islanders and their knowledge-practice-belief systems have a long history of resilience to environmental variability and unpredict- ability, including periodic and severe disturbances (e.g., droughts, floods, storms, and tsunamis) (McMillen et al., 2014). Improved climate predictions can assist governments and coastal communities in reducing the impacts of climatic variability, but policy and management responses will need to be adaptive to the same time scales as climatic variability (Dunstan et al., 2018). While reductions in $\mathrm{CO}_{2}$ are the only way to reverse climate change, reducing non-climate stresses that contribute to ecosystem degradation can moderate the vulnerability of species and ecosystems to direct climate change impacts. Modeling results suggest that strong local mitigation measures (e.g., regional fishing allocation schemes, effective MPA networks, decentralized coastal management) can substantially reduce fisheries declines, particularly in areas that are projected to have the largest decreases in catch (Asch et al., 2018). Community-based and participatory approaches can complement and ground-truth climate models and guide culturally appropriate resource management, research, and adaptation measures (McMillen et al., 2014).

\section{Other global threats}

Illegal, unreported, and unregulated (IUU) fishing is an ever- growing existential threat to the Pacific region. IUU fishing harms legitimate fishing activities and livelihoods, jeopardizes food and economic security, benefits transnational crime, distorts markets, con- tributes to human trafficking, and undermines ongoing efforts to implement sustainable fisheries policies (Petrossian, 2015). International efforts to counter IUU fishing have grown over the past decades. Advances in satellite technology and vessel tracking had made huge advances in surveillance. The public accessibility of automatic ship identification system (AIS) data has made it possible to observe vessel activity anywhere in the world and has revolutionized how we monitor fisheries (Kroodsma et al., 2018). Curtailing IUU fishing can produce rapid improvements in fishery profits and catches and creates an opportunity for countries to reform their fisheries while avoiding many of the short-run costs of reducing domestic fishing efforts and catches (Cabral et al., 2018). The recent implementation of the Port State Measures Agreement establishes a minimum set of standard measures for States to apply when foreign vessels seek entry into their ports and verifies that such vessels have not engaged in IUU fishing and other inspection and enforcement violations (FAO, 2016).

As more Pacific Island countries and territories have increased management of their EEZs, fishing effort has shifted to the adjacent high seas where rules of fishing are less rigorous, and revenues are not shared with island nations. Recent research shows that closing the high seas to fishing would increase fisheries yield in countries' exclusive economic zones by $30 \%$ and fisheries profits by $>100 \%$ (White and Costello, 2014). This would also increase the social equitability of fishing, by shifting benefits to local fishers and away from large foreign fleets (Sumaila et al., 2015). 
Deep-sea mineral companies are particularly interested in the exploration and exploitation of the rich mineral deposits of the Pacific region. The Clarion-Clipperton Fracture Zone (CCZ) in the abyssal eastern Pacific has the largest known concentrations of high-value polymetallic nodules, and the International Seabed Authority (ISA), created under the Law of the Sea Convention, has granted numerous contracts to explore for minerals on the deep seabed in this region (Wedding et al., 2015). Because of the scale of the impacts and the sensitivity of the deep sea, the ISA developed a precautionary approach in the CCZ by developing the deep seabed's first environmental management plan, and one that included MPAs based on the recommendations of a scientific working group (Wedding et al., 2015). The Cook Islands and Kiribati have implemented national deep-sea mineral policies, and many other countries in the region have draft policies or existing legislation that includes management of national deep-sea mineral resources (Govan, 2017).

\section{Whole-island and whole-ocean approaches}

The connectivity between terrestrial and marine ecosystems in nearly all aspects of life in Oceania requires a major shift from current thinking toward a more integrated approach. Marine spatial planning (MSP) is a strategic, coordinated, and comprehensive effort that pro- vides a framework for engaging stakeholders at all levels to maximize resilience of ecosystems and communities (Crowder et al., 2006). MSP can help mitigate some threats by planning for sustainable coastal development, appropriate waste and marine pollution management, and best practices for watershed and marine resource management (Grantham et al., 2011).

Trends toward adaptive management are essential in this time of rapid environmental change. While larger MPAs are thought to be better buffers from the effects of climate change, the small size of many MPAs in developing nations means that adaptive management can be done by communities and decisions can be made and implemented rapidly (Aswani et al., 2007; Ban et al., 2011). In the Republic of the Marshall Islands, atoll communities have formed Natural Resource Management Committees, with responsibilities for assessing environ- mental impacts and making recommendations for management implementation (Baker et al., 2011). The Cook Islands recent declaration to declare their entire EEZ as an LSMPA may represent a model for achieving integrated ocean management and conservation through inclusive processes of consultation and spatial planning.

Understanding how to build effective, culturally grounded measurement systems is a fundamental step toward supporting adaptive management and resilience in the face of environmental, social, and economic change (Sterling et al., 2017a). By incorporating multiple worldviews and knowledge systems, biocultural approaches can help better understand the links in social-ecological systems and increase the chances of long-term 
success of conservation interventions (Gavin et al., 2015; Sterling et al., 2017b). These hybrid systems have limitations as not all views and values have equal importance, and rapid cultural and environmental changes will require a prioritization of goals and objectives that are largely place-based.

The increasing threats of climate change impacts, coupled with declining coastal fisheries and food security challenges requires bottom- up, as well as top-down governance that will benefit from traditional ecological knowledge that is adapted to a modern and changing planet. The people of Oceania are at the frontline of climate change and while these changes will fundamentally change the world of the future in ways we cannot fully predict, the resilience shown by the people of Oceania in the past gives us some hope.

\section{Acknowledgements}

I would like to thank Claudio Compagna, Cindy Hunter, and Rachel Dacks who provided useful discussions and comments on this manuscript. This review article was supported in part by National Geographic Society Pristine Seas. This article is dedicated to Charles Sheppard and his life-long contribution to marine conservation as viewed through a lens that has profoundly influenced my thinking and research during my career.

\section{References}

Abbott, L.A., 1984. Limu. An Ethnobotanical Study of Hawaiian Seaweeds. PacificTropical Garden, Honolulu.

Allen, M.S., 2007. Three millennia of human and sea turtle interactions in remote Oceania. Coral Reefs 26 (4), 959-970.

Asch, R.G., Cheung, W.W., Reygondeau, G., 2018. Future marine ecosystem drivers, biodiversity, and fisheries maximum catch potential in Pacific Island countries and territories under climate change. Mar. Policy 88, 285-294.

Aswani, S., 2005. Customary sea tenure in Oceania as a case of rights-based fishery management: does it work? Rev. Fish Biol. Fish. 15 (3), 285-307.

Aswani, S., Lauer, M., 2006. Incorporating fishermen's local knowledge and behavior into geographical information systems (GIS) for designing marine protected areas in Oceania. Hum. Organ. 65 (1), 81-102.

Aswani, S., Albert, S., Sabetian, A., Furusawa, T., 2007. Customary management as pre- cautionary and adaptive principles for protecting coral reefs in Oceania. Coral Reefs 26 (4), 1009.

Aswani, S., Christie, P., Muthiga, N.A., Mahon, R., Primavera, J.H., Cramer, L.A., Barbier, E.B., Granek, E.F., Kennedy, C.J., Wolanski, E., Hacker, S., 2012. The way forward with ecosystembased management in tropical contexts: reconciling with existing management systems. Mar. Policy 36 (1), 1-10.

Aswani, S., Ruddle, K., 2013. Design of realistic hybrid marine resource management programs in Oceania. Pac. Sci. 67 (3), 461-476. 
Ayers, A.L., Kittinger, J.N., 2014. Emergence of co-management governance for Hawai'i coral reef fisheries. Glob. Environ. Chang. 28, 251-262.

Baker, N., Beger, M., McClennen, C., Ishoda, A., Edwards, F., 2011. Reimaanlok: a na- tional framework for conservation area planning in the Marshall Islands. J. Mar. Biol. 2011, 273034.

Bambridge, T., 2016. The Rahui: Legal Pluralism in Polynesian Traditional Management of Resources and Territories. Anu Press.

Ban, N.C., Adams, V.M., Almany, G.R., Ban, S., Cinner, J.E., McCook, L.J., Mills, M., Pressey, R.L., White, A., 2011. Designing, implementing and managing marine pro- tected areas: emerging trends and opportunities for coral reef nations. J. Exp. Mar. Biol. Ecol. 408 (1-2), 21-31.

Barclay, K., 2014. History of industrial tuna fishing in the Pacific Islands. In: Historical Perspectives of Fisheries Exploitation in the Indo-Pacific. Springer, Dordrecht, pp. 153-171.

Bartlett, C.Y., Pakoa, K., Manua, C., 2009. Marine reserve phenomenon in the Pacific islands. Mar. Policy 33 (4), 673-678.

Bell, J.D., Ganachaud, A., Gehrke, P.C., Griffiths, S.P., Hobday, A.J., Hoegh-Guldberg, O., Johnson, J.E., Le Borgne, R., Lehodey, P., Lough, J.M., Matear, R.J., 2013. Mixed responses of tropical Pacific fisheries and aquaculture to climate change. Nat. Clim. Chang. 3 (6), 591.

Bellwood, P.S., 1980. The peopling of the Pacific. Sci. Am. 243 (5), 174-185.

Bennett, N.J., Govan, H., Satterfield, T., 2015. Ocean grabbing. Mar. Policy 57, 61-68. Berkes, F., 2012. Sacred Ecology. Routledge, New York.

Brewer, T.D., Cinner, J.E., Green, A., Pressey, R.L., 2013. Effects of human population density and proximity to markets on coral reef fishes vulnerable to extinction by fishing. Conserv. Biol. 27 (3), 443-452.

Bromhead, D., Scholey, V., Nicol, S., Margulies, D., Wexler, J., Stein, M., Hoyle, S., Lennert-Cody, C., Williamson, J., Havenhand, J., Ilyina, T., 2015. The potential im- pact of ocean acidification upon eggs and larvae of yellowfin tuna (Thunnus alba-cares). Deep-Sea Res. II Top. Stud.

Oceanogr. 113, 268-279.

Cabral, R.B., Mayorga, J., Clemence, M., Lynham, J., Koeshendrajana, S., Muawanah, U., Nugroho, D., Anna, Z., Ghofar, A., Zulbainaeni, N., Gaines, S.D., Costelle, C., 2018. Rapid and lasting gains from solving illegal fishing. Nat. Ecol. Evol. 2, 650-658.

Campbell, J.R., 2015. Development, global change and traditional food security in Pacific Island countries. Reg. Environ. Chang. 15 (7), 1313-1324.

Carson, M.T., Kurashina, H., 2012. Re-envisioning long-distance Oceanic migration: early dates in the Mariana Islands. World Archaeol. 44 (3), 409-435.

Chapman, M.D., 1985. Environmental influences on the development of traditional conservation in the South Pacific region. Environ. Conserv. 12 (3), 217-230.

Chapman, M.D., 1987. Traditional political structure and conservation in Oceania. Ambio 16 (4), 201-205.

Cheung, W.W., Reygondeau, G., Frölicher, T.L., 2016. Large benefits to marine fisheries of meeting the $1.5 \mathrm{C}$ global warming target. Science 354 (6319), 1591-1594.

Cinner, J., 2005. Socioeconomic factors influencing customary marine tenure in the Indo- Pacific. Ecol. Soc. 10 (1).

Cinner, J.E., Aswani, S., 2007. Integrating customary management into marine con- servation. Biol. Conserv. 140 (3-4), 201-216.

Cinner, J., Huchery, C., 2014. A comparison of social outcomes associated with different fisheries co-management institutions. Conserv. Lett. 7 (3), 224-232. 
Cinner, J.E., Kittinger, J.N., 2015. Linkages between social systems and coral reefs. In: Mora, Camilo (Ed.), Ecology of Fishes on Coral Reefs. Cambridge University Press, Cambridge, UK, pp. 215220.

Cinner, J., Marnane, M.J., McClanahan, T.R., Almany, G.R., 2006. Periodic closures as adaptive coral reef management in the Indo-Pacific. Ecol. Soc. 11 (1).

Cinner, J.E., McClanahan, T.R., MacNeil, M.A., Graham, N.A., Daw, T.M., Mukminin, A., Feary, D.A., Rabearisoa, A.L., Wamukota, A., Jiddawi, N., Campbell, S.J., 2012.

Comanagement of coral reef social-ecological systems. Proc. Natl. Acad. Sci. 109 (14), 52195222.

Clarke, P., Jupiter, S.D., 2010. Law, custom and community-based natural resource management in Kubulau District (Fiji). Environ. Conserv. 37 (1), 98-106.

Colchester, M., 2004. Conservation policy and indigenous peoples. Environ. Sci. Pol. 7 (3), 145153.

Colding, J., Folke, C., 2001. Social taboos: "invisible" systems of local resource man- agement and biological conservation. Ecol. Appl. 11 (2), 584-600.

Corrin Care, J., Zorn, J.G., 2001. Legislating pluralism: statutory 'developments' in Melanesian customary law. J. Leg. Pluralism Unofficial Law 33 (46), 49-101.

Crowder, L.B., Osherenko, G., Young, O.R., Airamé, S., Norse, E.A., Baron, N., Day, J.C., Douvere, F., Ehler, C.N., Halpern, B.S., Langdon, S.J., 2006. Resolving mismatches in US ocean governance. Science 313 (5787), 617.

Dahl, A.L., 2017. Island conservation issues in international conventions and agreements. Environ. Conserv. 44 (3), 1-19.

De Mitcheson, Y.S., Cornish, A., Domeier, M., Colin, P.L., Russell, M., Lindeman, K.C., 2008. A global baseline for spawning aggregations of reef fishes. Conserv. Biol. 22 (5), 1233-1244.

Devillers, R., Pressey, R.L., Grech, A., Kittinger, J.N., Edgar, G.J., Ward, T., Watson, R., 2015. Reinventing residual reserves in the sea: are we favouring ease of establish- ment over need for protection? Aquat. Conserv. Mar. Freshwat. Ecosyst. 25 (4), 480-504.

Dunstan, P.K., Moore, B.R., Bell, J.D., Holbrook, N.J., Oliver, E.C., Risbey, J., Foster, S.D., Hanich, Q., Hobday, A.J., Bennett, N.J., 2018. How can climate predictions improve sustainability of coastal fisheries in Pacific Small-Island Developing States? Mar.

Policy 88, 295-302.

FAO, 2016. Agreement on Port State Measures to Prevent, Deter, and Eliminate Illegal, Unreported and Unregulated Fishing. Food and Agriculture Organization of the United Nations, Roma, Italy.

Finney, B.R., 1977. Voyaging canoes and the settlement of Polynesia. Science 196, 1277-1285.

Foale, S., Manele, B., 2004. Social and political barriers to the use of marine protected areas for conservation and fishery management in Melanesia. Asia Pacific Viewpoint 45 (3), 373-386.

Foale, S., Cohen, P., Januchowski-Hartley, S., Wenger, A., Macintyre, M., 2011. Tenure and taboos: origins and implications for fisheries in the Pacific. Fish Fish. 12 (4), 357-369.

Foale, S., Dyer, M., Kinch, J., 2016. The value of tropical biodiversity in rural Melanesia. Valuation Studies 4 (1), 11-39.

Friedlander, A.M., Ziemann, D.A., 2003. Impact of hatchery releases on the recreational fishery for Pacific threadfin (Polydactylus sexfilis) in Hawaii. Fish. Bull. 101 (1), 32-43.

Friedlander, A., Poepoe, K., Poepoe, K., Helm, K., Bartram, P., Maragos, J., Abbott, I., 2002. Application of Hawaiian traditions to community-based fishery management. In: Proceedings 
of the Ninth International Coral Reef Symposium, Bali, 23-27 October 2000, vol. 2. pp. 813815.

Friedlander, A.M., Shackeroff, J.M., Kittinger, J.N., 2013. Customary marine resource knowledge and use in contemporary Hawai'i. Pac. Sci. 67 (3), 441-460.

Friedlander, A.M., Stamoulis, K.A., Kittinger, J.N., Drazen, J.C., Tissot, B.N., 2014. Understanding the scale of marine protection in Hawai'i: from community-based management to the remote Northwestern Hawaiian Islands. Adv. Mar. Biol. 69, 153-203 (Academic Press).

Friedlander, A.M., Wagner, D., Gaymer, C.F., Wilhelm, T.A., Lewis, N.A., Brooke, S., Kikiloi, K., Varmer, O., 2016. Co-operation between large-scale MPAs: successful experiences from the Pacific Ocean. Aquat. Conserv. Mar. Freshwat. Ecosyst. 26 (S2), 126-141.

Friedlander, A.M., Golbuu, Y., Ballesteros, E., Caselle, J.E., Gouezo, M., Olsudong, D., Sala, E., 2017. Size, age, and habitat determine effectiveness of Palau's Marine Protected Areas. PLoS One 12 (3), e0174787.

Gavin, M.C., McCarter, J., Mead, A., Berkes, F., Stepp, J.R., Peterson, D., Tang, R., 2015. Defining biocultural approaches to conservation. Trends Ecol. Evol. 30 (3), 140-145.

Gillett, R., 2009. Fisheries in the Economies of the Pacific Island Countries and Territories. Asian Development Bank.

Gillett, R., Cartwright, I., 2010. The Future of Pacific Island Fisheries. Secretariat of the Pacific Community, Noumea and the Forum Fisheries Agency, Honiara.

Gourlie, D., Davis, R., Govan, H., Marshman, J., Hanich, Q., 2018. Performing "A New Song”: suggested considerations for drafting effective coastal fisheries legislation under climate change. Mar. Policy 88, 342-349.

Govan, H., 2015. Preliminary Review of Public Expenditure of the Fisheries Agencies of Pacific Island Countries and Territories: Policy, Operational Budget and Staffing Support for Coastal Fisheries. Report for Secretariat of the Pacific Community. FAME Division, Noumea. http://dx.doi.org/10.13140/RG.2.1.4949.9363. http://bit.ly/ FishPEIR.

Govan, H., 2017. Ocean governance - our sea of islands. In: Katafono, R. (Ed.), A Sustainable Future for Small States: Pacific 2050. Commonwealth Secretariat, London (ISBN 978-1-84929163-7).

Govan, H., et al., 2009. Status and Potential of Locally-managed Marine Areas in the South Pacific: Meeting Nature Conservation and Sustainable Livelihood Targets Through Wide-spread Implementation of LMMAs. SPREP/WWF/WorldFish- Reefbase/CRISP.

Govan, H., Kinch, J., Brjosniovschi, A., 2013. Strategic Review of Inshore Fisheries Policies and Strategies in Melanesia-Fiji, New Caledonia, Papua New Guinea, Solomon Islands and VanuatuPart II: Country Reports to the Secretariat of the Pacific Community for the Melanesian Spearhead Group, Noumea, New Caledonia. http:// bit.ly/1dhlxv4.

Grantham, H.S., McLeod, E., Brooks, A., Jupiter, S.D., Hardcastle, J., Richardson, A.J., Poloczanska, E.S., Hills, T., Mieszkowska, N., Klein, C.J., Watson, J.E.M., 2011. Ecosystem-based adaptation in marine ecosystems of tropical Oceania in response to climate change. Pac. Conserv. Biol. 17 (3), 241-258.

Grorud-Colvert, K., Claudet, J., Tissot, B.N., Caselle, J.E., Carr, M.H., Day, J.C., Friedlander, A.M., Lester, S.E., De Loma, T.L., Malone, D., Walsh, W.J., 2014. Marine protected area networks: assessing whether the whole is greater than the sum of its parts. PLoS One 9 (8), e102298.

Gruby, R.L., Basurto, X., 2013. Multi-level governance for large marine commons: politics and polycentricity in Palau's protected area network. Environ. Sci. Pol. 33, 260-272. 
Hanich, Q., Wabnitz, C.C., Ota, Y., Amos, M., Donato-Hunt, C., Hunt, A., 2018. Small- scale fisheries under climate change in the Pacific Islands region. Mar. Policy 279-284.

Helfman, G.S., Randall, J.E., 1972. Palauan fish names. Pac. Sci. 27 (2), 136-153.

Hickey, F.R., Johannes, R.E., 2002. Recent evolution of village-based marine resource management in Vanuatu. In: SPC Traditional Marine Resource Management and Knowledge Information Bulletin. 14. pp. 8-21.

Hoffmann, T.C., 2002. Coral reef health and effects of socio-economic factors in Fiji and Cook Islands. Mar. Pollut. Bull. 44 (11), 1281-1293.

Houk, P., Camacho, R., Johnson, S., McLean, M., Maxin, S., Anson, J., et al., 2015. The Micronesia Challenge: assessing the relative contribution of stressors on coral reefs to facilitate science-tomanagement feed-back. PLoS One 18, e0130823.

Hviding, E., 1998. Contextual flexibility: present status and future of customary marine tenure in Solomon Islands. Ocean Coast. Manag. 40, 253-269.

Johannes, R.E., 1978. Traditional marine conservation methods in Oceania and their demise. Annu. Rev. Ecol. Syst. 9 (1), 349-364.

Johannes, R.E., 1981. Words of the Lagoon: Fishing and Marine Lore in the Palau District of Micronesia. Univ of California Press.

Johannes, R.E., 1982. Traditional conservation methods and protected marine areas in Oceania. Ambio 11-5 (11), 258-261.

Johannes, R.E., 1989. Managing small-scale fisheries in Oceania: unusual constraints and opportunities. In: Campbell, H., Menz, K., Waugh, G. (Eds.), Economics of Fisheries Management in the Pacific Islands Region. Australian Centre for International Agricultural Research, Canberra, A.C.T., pp. 85-93.

Johannes, R.E., 1998a. The case for data-less marine resource management: examples from tropical nearshore finfisheries. Trends Ecol. Evol. 13 (6), 243-246.

Johannes, R.E., 1998b. Government-supported, village-based management of marine resources in Vanuatu. Ocean Coast. Manag. 40 (2-3), 165-186.

Johannes, R.E., 2002a. Did indigenous conservation ethics exist. In: SPC Traditional Marine Resource Management and Knowledge Information Bulletin, vol. 14. pp. 3-7.

Johannes, R.E., 2002b. The renaissance of community-based marine resource manage- ment in Oceania. Annu. Rev. Ecol. Syst. 33 (1), 317-340.

Johannes, R.E., MacFarlane, J.W., 1991. Traditional Fishing in the Torres Strait Islands. CSIRO Division of Fisheries, Marine Laboratories, Hobart, Tasmania.

Johannes, R.E., Yeeting, B., 2001. I-Kiribati knowledge and management of Tarawa's lagoon resources. Atoll Res. Bull. 489, 1-24.

Jupiter, S., 2017. Culture, kastom and conservation in Melanesia: what happens when worldviews collide? Pac. Conserv. Biol. 23 (2), 139-145.

Jupiter, S.D., Egli, D.P., 2011. Ecosystem-based management in Fiji: successes and chal- lenges after five years of implementation. J. Mar. Biol. 2011.

Jupiter, S.D., Cohen, P.J., Weeks, R., Tawake, A., Govan, H., 2014. Locally-managed marine areas: multiple objectives and diverse strategies. Pac. Conserv. Biol. 20 (2), 165-179.

Kikiloi, K., Friedlander, A.M., Wilhelm, A., Lewis, N.A., Quiocho, K., 'Āila Jr., W., Kaho'ohalahala, S., 2017. Papahānaumokuākea: integrating culture in the design and management of one of the world's largest marine protected areas. Coast. Manag. 45 (6), 436-451.

Kittinger, J.N., Cinner, J.E., Aswani, S., White, A.T., 2014. Back to the future: integrating customary practices and institutions into comanagement of small-scale fisheries. In: Kittinger (Ed.), 
Marine Historical Ecology in Conservation: Applying the Past to Manage for the Future, pp. 135-160.

Kroodsma, D.A., Mayorga, J., Hochberg, T., Miller, N.A., Boerder, K., Ferretti, F., Wilson, A., Bergman, B., White, T.D., Block, B.A., Woods, P., 2018. Tracking the global footprint of fisheries. Science 359 (6378), 904-908.

Lal, B.V., Fortune, K. (Eds.), 2000. The Pacific Islands: An Encyclopedia. vol. 1 University of Hawaii Press.

Leenhardt, P., Cazalet, B., Salvat, B., Claudet, J., Feral, F., 2013. The rise of large-scale marine protected areas: conservation or geopolitics? Ocean Coast. Manag. 85, 112-118.

Levine, A., Richmond, L., 2014. Examining enabling conditions for community-based fisheries comanagement: comparing efforts in Hawai'i and American Samoa. Ecol. Soc. 19 (1).

McClenachan, L., Kittinger, J.N., 2013. Multicentury trends and the sustainability of coral reef fisheries in Hawai'i and Florida. Fish Fish. 14 (3), 239-255.

McMillen, H.L., Ticktin, T., Friedlander, A., Jupiter, S.D., Thaman, R., Campbell, J., Veitayaki, J., Giambelluca, T., Nihmei, S., Rupeni, E., Apis-Overhoff, L., 2014. Small islands, valuable insights: systems of customary resource use and resilience to climate change in the Pacific. Ecol. Soc. 19 (4).

Mills, M., Jupiter, S.D., Pressey, R.L., Ban, N.C., Comley, J., 2011. Incorporating effec- tiveness of community-based management in a national marine gap analysis for Fiji. Conserv. Biol. 25 (6), 1155-1164.

Muehlig-Hofmann, A., 2007. Traditional authority and community leadership: key factors in community-based marine resource management and conservation. In: SPC Traditional Marine Resource Management and Knowledge Information Bulletin, vol. 21. pp. 31-44.

O'Leary, B.C., Ban, N.C., Fernandez, M., Friedlander, A.M., García-Borboroglu, P., Golbuu, Y., Guidetti, P., Harris, J.M., Hawkins, J.P., Langlois, T., McCauley, D.J., 2018.

Addressing criticisms of large-scale marine protected areas. Bioscience 68 (5), 359-370.

Petrossian, G.A., 2015. Preventing illegal, unreported and unregulated (IUU) fishing: a situational approach. Biol. Conserv. 189, 39-48.

Poepoe, K., Bartram, P., Friedlander, A., 2007. The use of traditional Hawaiian knowledge in the contemporary management of marine resources. In: Haggan, N., Neis, B., Baird, I. (Eds.), Fishers' Knowledge in Fisheries Science and Management. UNESCO, Paris, pp. 117141.

Preston, G.L., 1993. Beche-de-mer. In: Nearshore Marine Resources of the South Pacific: Information for Fisheries Development and Management. Forum Fisheries Agency, Honiara, Solomon Islands, pp. 371-401.

Randall, J.E., Cea, A., 2011. Shore Fishes of Easter Island. University of Hawai'i Press.

Ruddle, K., 1988. Social principles underlying traditional inshore fishery management systems in the Pacific Basin. Mar. Resour. Econ. 5 (4), 351-363.

Ruddle, K., 1996. Traditional management of reef fishing. In: NVC, Pollunin, Roberts, C.M.P. (Eds.), Reef Fisheries. Springer, Netherlands, pp. 315-335.

Ruddle, K., Hickey, F.R., 2008. Accounting for the mismanagement of tropical nearshore fisheries. Environ. Dev. Sustain. 10 (5), 565-589.

Ruddle, K., Hviding, E., Johannes, R.E., 1992. Marine resources management in the context of customary tenure. Mar. Resour. Econ. 7 (4), 249-273.

Sand, C., 2002. Melanesian tribes vs. Polynesian chiefdoms: recent archaeological as- sessment of a classic model of sociopolitical types in Oceania. Asian Perspect. 41 (2), 284-296. 
Schug, D., 2001. Hawaii's commercial fishing industry: 1820-1945. Hawaii. J. Hist. 35, $15-34$. Sheppard, P.J., Bedford, S., Bellwood, P., Burley, D.V., Chiu, S., Irwin, G., Kirch, P.V., Lilley, I., Matisoo-Smith, L., Pawley, A., Ross, M., 2011. Lapita colonization across the Near/Remote Oceania boundary. Curr. Anthropol. 52 (6), 799-840.

Sterling, E., Ticktin, T., Morgan, T.K.K., Cullman, G., Alvira, D., Andrade, P., Bergamini, N., Betley, E., Burrows, K., Caillon, S., Claudet, J., 2017a. Culturally grounded in- dicators of resilience in social-ecological systems. Environ. Soc. 8 (1), 63-95.

Sterling, E.J., Filardi, C., Toomey, A., Sigouin, A., Betley, E., Gazit, N., Newell, J., Albert, S., Alvira, D., Bergamini, N., et al., 2017b. Biocultural approaches to well-being and sustainability indicators across scales. Nat. Ecol. Evol. 1 (12), 1798.

Sumaila, U.R., Lam, V.W., Miller, D.D., Teh, L., Watson, R.A., Zeller, D., Cheung, W.W., Côté, I.M., Rogers, A.D., Roberts, C., Sala, E., 2015. Winners and losers in a world where the high seas is closed to fishing. Sci. Rep. 5, 8481.

Tainter, J.A., 2006. Archaeology of overshoot and collapse. Annu. Rev. Anthropol. 35, 59-74.

Thaman, K.H., 1993. Culture and the curriculum in the South Pacific. Comp. Educ. 29 (3), 249-

260.

Titcomb, M., 1972. Native use of fish in Hawai'i. University of Hawai'i Press, Honolulu, Hawai'i. Titcomb, M., 1978. Native use of marine invertebrates in old Hawaii. Pac. Sci. 32, 325-375.

Toonen, R.J., Wilhelm, T.A., Maxwell, S.M., Wagner, D., Bowen, B.W., Sheppard, C.R., Taei, S.M.,

Teroroko, T., Moffitt, R., Gaymer, C.F., Morgan, L., Lewis, N., Sheppard, A.L.S., Parks, J.,

Friedlander, A.M., Big Ocean Think Tank, 2013. One size does not fit all: the emerging frontier in

large-scale marine conservation. Mar. Pollut. Bull. 77 (1-2), 7-10.

UNEP-WCMC and IUCN, 2018. Marine Protected Planet. UNEP-WCMC and IUCN, Cambridge, UK

Available at: www.protectedplanet.net (On-line, March, 2018).

Veitayaki, J, 2000. Fisheries resource-use culturejn Fiji and its implications. In: Hooper,A. (Ed.), Culture and'Sustainable Development in the Pacific, pp. 116-130. Vierros, M., Tawake, A., Hickey, F., Tiraa, A., Noa, R., 2010. Traditional Marine

Management Areas of the Pacific in the Context of National and International Law and Policy.

United Nations University, Traditional Knowledge Initiative, Darwin, Australia.

Wamukota, A.W., Cinner, J.E., McClanahan, T.R., 2012. Co-management of coral reef fisheries: a critical evaluation of the literature. Mar. Policy 36 (2), 481-488.

Ward, R.G., 1972. The Pacific bêche-de-mer trade with special reference to Fiji. In: Ward,

R.G. (Ed.), Man in the Pacific Islands: Essays on Geographical Change in the Pacific Islands, pp.

91-123.

Wedding, L.M., Reiter, S.M., Smith, C.R., Gjerde, K.M., Kittinger, J.N., Friedlander, A.M., Gaines,

S.D., Clark, M.R., Thurnherr, A.M., Hardy, S.M., Crowder, L.B., 2015.

Managing mining of the deep seabed. Science 349 (6244), 144-145.

Weeks, R., Jupiter, S.D., 2013. Adaptive comanagement of a marine protected area net- work in

Fiji. Conserv. Biol. 27 (6), 1234-1244.

White, C., Costello, C., 2014. Close the high seas to fishing? PLoS Biol. 12 (3), e1001826. Wilhelm,

T.A., Sheppard, C.R., Sheppard, A.L., Gaymer, C.F., Parks, J., Wagner, D., Lewis, N., 2014. Large marine protected areas-advantages and challenges of going big.

Aquat. Conserv. Mar. Freshwat. Ecosyst. 24 (S2), 24-30. 